\title{
IMPACT OF THE CURRENT LEVEL IN THE DEVELOPMENT OF THE TELECOMMUNICATION-INFORMATION SYSTEM OF THE SERBIAN ARMED FORCES ON THE DEFENSE OF THE REPUBLIC OF SERBIA
}

\author{
Hatidža A. Beriša ${ }^{a}$, Olga M. Zorićb \\ University of Defence in Belgrade, School of National Defense, \\ Belgrade, Republic of Serbia \\ a e-mail: hatidza.berisa@mod.gov.rs, \\ ORCIDiD: (1)http://orcid.org/0000-0002-9432-5273 \\ b e-mail: olgazoric@yahoo.com, \\ ORCIDiD: (1Dhttp://orcid.org/0000-0002-6378-3554
}

DOI: 10.5937/vojtehg67-19274; https://doi.org/10.5937/vojtehg67-19274

FIELD: Telecommunications

ARTICLE TYPE: Professional Paper

ARTICLE LANGUAGE: English

\section{Abstract:}

Information, as one of the important factors of armed conflicts, greatly influences the physiognomy, the direction and the speed of the development of contemporary conflicts. It expresses the availability of knowledge and data necessary for successful command and control at all levels. Its availability reduces the uncertainty in military activity and enables a better assessment of the situation, as well as making relevant decisions in real time. In the paper, the Telecommunications and Information System (TkIS) of the Serbian Armed Forces (SAF) is looked at from several aspects, and the issue of the need for improvement of the existing system, imposed by constant development of information technologies, is being updated. The concept, purpose, structure and level of development of the TkIS are dealt with in the paper, particularly the level of development of the SAF TkIS and its cause-effect relation with the defense of the Republic of Serbia, with a focus on military defense. The aim of this paper is to examine the impact of the Serbian Armed Forces telecommunications and information system on the defense of the Republic of Serbia with the emphasis on military defense, and to point out the need for continuous improvement of the TkIS and continuous education, i.e. adequate and timely training of the personnel for its use for military defense. The importance of the work is in the analyzed state of the Serbian Telecommunications and Information System in relation to the 
needs of the military defense of the Republic of Serbia in the context of contemporary security challenges.

Key words: information, telecommunications, Serbian Armed Forces, military defense, satellite networks, fixed networks, internet.

\section{Introduction}

In accordance with the security environment and with recognized challenges, risks and threats to the defense, the Republic of Serbia has defined its vital defense interests. Defense interests are an expression of the highest values and needs of the Republic of Serbia that are constantly being realized and improved, and they as such represent the purpose of existence and functioning of the defense system. Creating a unique and efficient defense system of the Republic of Serbia is possible only with a comprehensive and sustainable development of both military and civil defense. The application of the concept of total defense, through the integral engagement of defense entities and defense potential, enables a uniform participation of all parts of society in the preservation and improvement of vital defense interests.

The command and control of military defense is carried out by the President of the Republic, the Minister of Defense and the Chief of the General Staff of the Serbian Armed Forces (SAF) in accordance with the Constitution, their authorizations by law and their competencies. The command and control of civil defense and other entities important for defense is a part of the unified command of the defense system and will be implemented within state bodies, state administration bodies, bodies of autonomous provinces, local self-government bodies, companies and other legal entities in accordance with the law. (Službeni glasnik RS, 88/2009)

Timely, complete and protected data and information for the needs of management, command and control of military and civil defense are provided by telecommunication-information systems in the Republic of Serbia. A TkIS is a set of facilities, devices and equipment that are interconnected in a technical and technological unit enabling the transmission of messages and information from one point to another. These systems have their structures, organizations and boundaries, and, to a certain extent, they are interrelated. All TkISs in the Republic of Serbia form a unified TkIS of the Republic of Serbia.

A telecommunications information system that enables the transmission of messages and information for the needs of military defense is the TkIS of the Serbian Armed Forces. The development of 
the SAF TkIS organization is focused on the best-in-depth experiences and the results of the scientific research in the field of telecommunications, information technology and information protection. The compatibility of the TkIS of the Serbian Armed Forces with other TkISs in the Republic of Serbia is one of the essential conditions for the realization of the unified command and control of the military and civil defense of the Republic of Serbia.

The purpose of the SAF TkIS is the telecommunications and information security of the Serbian Armed Forces. It is one of ten security fields in the Serbian Armed Forces and is conducted to collect, process, transfer, exchange and protect data and information in real time. The realization of telecommunications and IT security enables networking in support of visualization of operational environment, decision making process, selection of operation objects, synchronization of combat assets and tools, as well as information management.

As a weapon, information can be used as part of full or partial information superiority of one of the parties in conflict. The enemy will achieve full or partial information superiority over our forces when the telecommunications and information security of the Serbian Armed Forces are not able to provide a safe, continuous, elastic and operational system of command and control of the military defense in the Republic of Serbia.

The focus of the work will be to look at the state of the Serbian Telecommunications and Information System in relation to the needs of the military defense of the Republic of Serbia in the context of contemporary security challenges.

\section{The defense system of the Republic of Serbia}

The defense system of the Republic of Serbia is a part of the national security system, which represents a unique, normative, structured and functionally regulated entity, aimed at protecting the sovereignty, independence, territorial integrity and security of the Republic of Serbia from all forms of external and internal threats in peace, state of emergency and war (Službeni glasnik RS, 116/2007, $88 / 2009 \& 10 / 2015)$. The Republic of Serbia protects and realizes its vital defense interests through military and civil defense.

The Serbian Armed Forces are the military defense bearer while state bodies, state administration bodies, autonomous provinces bodies, local self-government bodies, companies, public services and other 
entities and forces of the defense system participate in civil defense. ${ }^{1}$ The Law on the Serbian Armed Forces describes the Serbian Armed Forces as an organized armed force that defends the country against armed threats from outside and performs other missions and tasks in accordance with the Constitution, the law and principles of international law regulating the use of force (Službeni glasnik RS, 116/2007, 88/2009\& 10/2015). In accordance with the Constitution, the National Assembly of the Republic of Serbia assigns missions to the Serbian Armed Forces for the protection of vital defense interests. The Serbian Armed Forces implement the stated mission by carrying out tasks (Medija centar "Odbrana“, 2010). The Serbian Armed Forces can realize the assigned missions only if the organization of the Serbian Armed Forces, the content of its preparations, use and security of the Serbian Armed Forces are harmonized and directed to the protection of vital defense interests. Commanding the Serbian Armed Forces is based on the principles of unity, continuity, elasticity, efficiency, operability and security (Medija centar "Odbrana“, 2010). It is organized at the strategic, operational and tactical level. At the strategic level, the Serbian Armed Forces are commanded and run by the President of the Republic of Serbia, the Minister of Defense and the Chief of General Staff of the Serbian Armed Forces. The President of the Republic of Serbia, on the basis of the Constitution and the Law on the Serbian Armed Forces, decides on the use of the Serbian Armed Forces and commands the Serbian Armed Forces in peace and war (Službeni glasnik RS, 98/2006). In accordance with the Law on the Army, the Minister of Defense coordinates and implements the established defense policy and manages the Serbian Armed Forces. Also, based on the Law on the Army and the Guidelines on Responsibilities, the Chief of General Staff of the Serbian Armed Forces commands and controls the Serbian Armed Forces (Figure 1).

At the operational level, command bearers are the commands of the branches and the training command, while at the tactical level, command bearers are the commands of brigades and other same-level commands, the commands of battalions-divisions and the commanders of units (from a company-battery to a team-service- crew). The command and control system in the Serbian Armed Forces will be largely determined by the possession and use of information. For all command levels in the Serbian

\footnotetext{
1 "The subjects of the defense system are: citizens, state bodies, companies, other legal entities, entrepreneurs and the Serbian Armed Forces. Defense forces are the human and material potentials of the Republic of Serbia, or the organized structure of the entities of the defense system. " (Službeni glasnik RS, 88/2009, p.14).
} 
Armed Forces, the possession of accurate, timely and relevant information will be enabled by the TkIS of the Serbian Armed Forces, through the realization of telecommunication-information security (TkIOb) at all levels (Medija centar „Odbrana“, 2010).

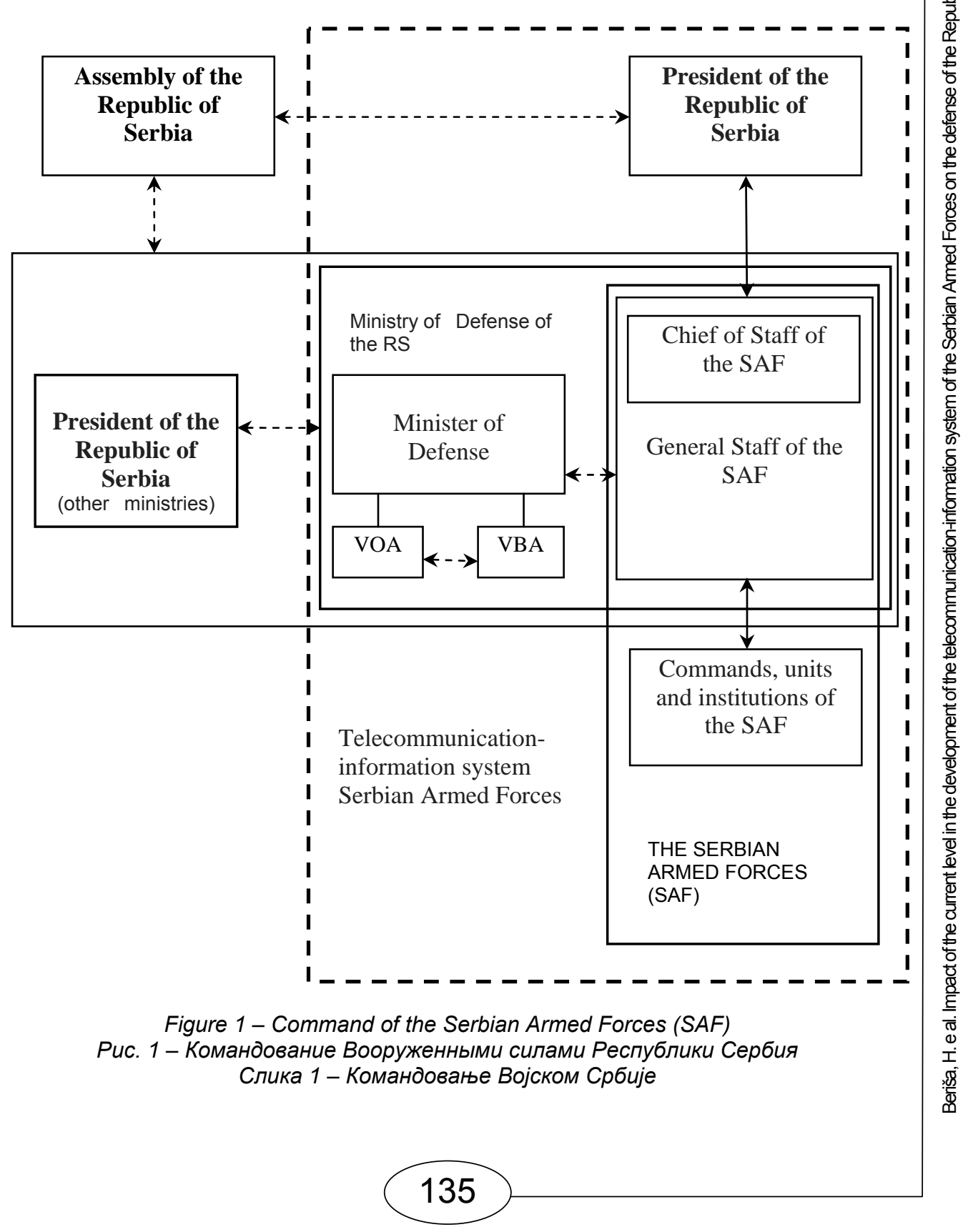


The telecommunication-information security of the military defense is an integral part of the Defense Plan of the Republic of Serbia, which defines the TkIOb of the President of the Republic, the Ministry of Defense and the Serbian Armed Forces (Službeni glasnik RS, 116/2007, $88 / 2009 \& 10 / 2015)$. It is important to point out that the dotted arrows indicate interrelationships.

Civil Defense is part of a unified defense system. It is organized at the level of the Republic of Serbia, the autonomous provinces and local self-government units. The Defense Law describes Civil Defense as part of the defense of the Republic of Serbia, which includes a set of measures and activities aimed at: preparing for defense and for the defense of the Republic of Serbia by non-military means; ensuring the successful functioning of state bodies, autonomous provinces and local self-government units, companies and other legal entities, protection and rescue and securing conditions for the life and work of citizens and meeting the needs of the defense forces in the state of emergency and war. Civil defense has assigned missions. (Službeni glasnik RS, $116 / 2007,88 / 2009$ \& 10/2015)

Civil defense missions are conducted by carrying out its tasks. In addition to the aforementioned missions and tasks, civil defense can also carry out other tasks based on the decisions of the legislative and executive authorities of the Republic, the autonomous provinces and local self-government units.

The command over civil defense and other defense-related entities is part of a unified defense command system and is carried out in accordance with the law. Providing telecommunications and services for the civil defense command is done through the TkIS for special purposes and through the TkIS for general needs (arrows point to interrelationships). The telecommunication-information security of civil defense is an integral part of the Civil Defense Plan of all entities.

\section{Telecommunication-information system of the Serbian Armed Forces}

The term telecommunication-information system denotes here a set of objects, devices and equipment interconnected in a technical and technological unit that allows the transmission of signals by means of cable, radio, optical or other electromagnetic means, including satellite networks, fixed networks (the Internet and other networks with switching circuits and packets), mobile networks, energy cable systems (in the part used for signal transmission) and networks for the distribution and 
broadcasting of media content, intended to enable the transmission of messages and information from one point to another. (Generalštab Vojske Srbije \& Medija centar „Odbrana“, 2012)

\section{Concept, purpose and structure of the} telecommunication-information system

The Republic of Serbia is a modern state aiming at the harmonization in all areas with the highest European and world standards. Harmonization in the field of telecommunications and IT can be achieved by rational, economical and efficient use of national resources (national radio-frequency spectrum), balanced development of telecommunication-information capacities and development of compatibility and interoperability of systems for their interconnection and utilization in order to obtain a unified technical and technological unit at the national and international level. There is a unified telecommunications and information system at the level of the Republic of Serbia in the field of telecommunications and information.

The unified TkIS of the Republic of Serbia consists of: telecommunication-information systems for general needs, telecommunication-information systems for special purposes and other holders of telecommunication-information assets (Figure 2). The telecommunication-information systems for general needs serve to provide various telecommunication and information services to individuals and legal entities. They represent the mainstay of the other TkISs in the Republic of Serbia. The TkISs for general needs include: TkIS of "Telekom Srbije", TkIS of "PTT Srbija", TkIS of "Radio Television of Serbia", TkIS of "VIP Telekom" and TkIS of "Telenor".

Telecommunication-information systems for special purposes are intended for securing certain organizations and realization of missions and tasks or activities. These systems include: TkIS of the Serbian Armed Forces (VS), TkIS of the Ministry of Internal Affairs (MUP), TkIS of the Ministry of Foreign Affairs (MIP), TkIS of the Security Information Agency (BIA), TkIS of the Serbian Railways (TS), TkIS of Elektroprivreda Srbije (EPS) and TkIS of the authorities responsible for rescue tasks, as well as emergency services. 


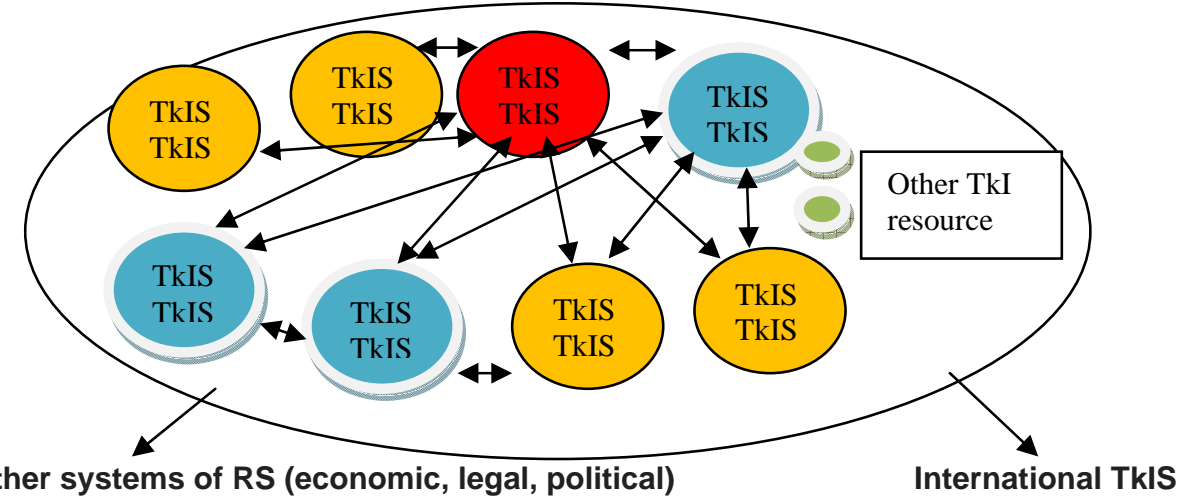

Figure 2 - General model of the telecommunications and information system in the Republic of Serbia (Generalštab Vojske Srbije \& Medija centar „Odbrana“, 2012)

Puc. 2 - Общая модель информационной и телекоммуникационно систем в Республике Сербия (Generalštab Vojske Srbije \& Medija centar „Odbrana“, 2012)

Слика 2 - Општи модел телекомуникационо-информационог система у

Републици Србији (Generalštab Vojske Srbije \& Medija centar „Odbrana“, 2012)

The telecommunications and information system of the Serbian Armed Forces belongs to the TkIS group for special purposes. It is intended for the implementation of the TKIOb of the Serbian Armed Forces. Telecommunication-information security is one of the security aspects in the Serbian Armed Forces and is important for ensuring the continuity, timeliness and quality of the functioning of the command and control of the Serbian Armed Forces in all missions and tasks. Telecommunication-information security represents a set of measures, procedures and activities by which the elements of TkIS, ready for operation or already operating in accordance with a certain plan of the TkIOb, are merged into a unified technical-technological entity (Generalštab Vojske Srbije \& Medija centar „Odbrana“, 2012). The mentioned system is closely related to the TkIS of "Telekom Srbija" and the TkIS of "PTT Serbia". The use of the capacities of the listed TkISs for the needs of the TkIS of the Serbian Armed Forces is done on the basis of laws, concluded contracts and approved plans of the defense of the Republic of Serbia. Through its elements, the TkIS of the Serbian Armed Forces is connected with other TkISs for special purposes, and also, depending on its needs, with other holders of telecommunications and information resources in the Republic of Serbia. (Politika, 2014)

The telecommunications and information system of the Army has its own structural and functional organization (Generalštab Vojske Srbije \& 
Medija centar "Odbrana“, 2012). The structural TkIS of the Serbian Armed Forces is divided into a stationary and mobile part, i.e. a stationary telecommunication-information system and a mobile telecommunication-information system (Figure 3). The stationary TkIS of the Serbian Armed Forces is the basis of the TkIS of the Serbian Armed Forces through which the capacities with the other TkISs in the Republic of Serbia are mostly integrated. The mobile TkIS consists of transport and transmission assets of the Tkl commands and units capable of operating in field conditions. The functionally mobile TkIS relies (utilizes the capacities) on the stationary TkIS. These systems consist of TkIS elements: stations, centers, nodes and telecommunication pathways.

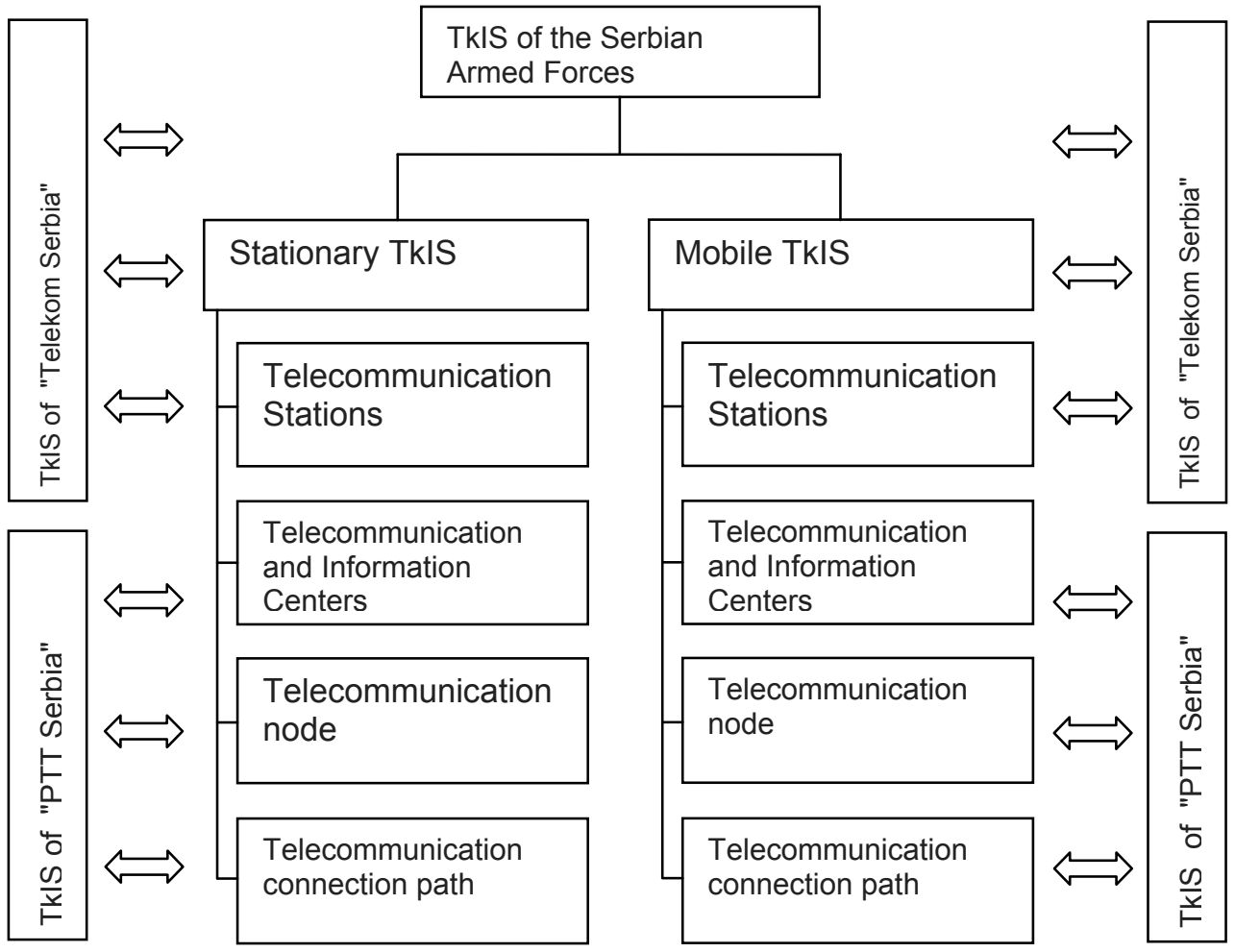

Figure 3 - Structured organization of the TkIS of the Serbian Armed Forces (Generalštab Vojske Srbije \& Medija centar „Odbrana“, 2012)

Puc. 3 - Структурная организация ТкИС Вооруженных сил Республики Сербия (Generalštab Vojske Srbije \& Medija centar „Odbrana“, 2012)

Слика 3 - Структурна организација ТкИС Војске Србије (Generalštab Vojske Srbije \& Medija centar „Odbrana“, 2012) 
The Serbian telecommunications and information system is functionally organized from the telecommunication component, the information component and the information protection component. All three components consist of specialized and trained personnel, appropriate equipment and appropriate work documents.

Achieved level of development of the telecommunications and information system of the Serbian Armed Forces

The SAF Telecommunications and Information System has its roots and experiences in the Yugoslav People's Army (JNA) where it had the name of the Armed Forces Communication System (SSNO, Uprava veza GS JNA, 1979) The organization and preparation of the Armed Forces Communication System (OS) were based on the experiences of the national liberation war and the concept of the national defense and social self-defense (ONO and DSZ). The experiences of the wars waged around the world at the time were also applied. The organization of the territory and the procurement of modern communication devices were established according to previous plans as well as the training of personnel and the integration of the OS system with the other holders of the Communication System in the SFRY. The usage of the capacities of the holders of the Communication System for general purposes and those of the holders of the Communication System for specific purposes was defined by the highest state acts of the SFR Yugoslavia for the defense of the country. The OS link system used mainly the JPTT capacities in the implementation of the tasks of the defense of the SFR Yugoslavia. $^{2}$ (Aksentijević \& Rošulj, 1984)

The Communication System in the Yugoslav Army consisted of a stationary part and a movable part. The basic elements of the Communication System were: communication stations, communication centers, communication nodes and communication paths. The planning, preparation, organization and operation of the Communication System were performed by communication organs, communication units and institutions. The communication organs were in the commands of regiments, brigades, divisions, corps, the army, and the General Staff of the Yugoslav Army. The highest communication body in the Yugoslav Army was the Office for Communication and Informatics.

2 "The Yugoslav Post, Telegraph and Telephone System (JPTT)" communication system serves to meet the needs of society, businesses and individuals in the use of postal, telegraph and telephone services in domestic and international traffic (Aksentijević \& Rošulj, 1984, p.45). 
During the 1990s war in Bosnia and Herzegovina, the Federal Republic of Yugoslavia was first under partial and later under full economic sanctions in accordance with the resolution of the Security Council. ${ }^{3}$ The economic sanctions also concerned trade in weapons and military equipment. Because of the above, the Yugoslav Army Communication System and the other holders of the communication system in the Federal Republic of Yugoslavia could not keep pace with technological and technological development and achievements in the field of telecommunications and informatics in the world. A major challenge for the Yugoslav Army's system of communications was the NATO (NATO, nd) aggression on the FRY lasting for 78 days in 1999 (Pečat, 2010). Some of the NATO priority targets were the command posts and the capacities of the communication system of the Yugoslav Army, but also the capacities of the other holders of the communication system of the Federal Republic of Yugoslavia. ${ }^{4}$ Most of the vital facilities of the Yugoslav Army's system of communications were damaged or destroyed. Immediately after the end of the NATO's aggression against the Federal Republic of Yugoslavia, the mitigation of the consequences of the actions on communication system infrastructure facilities began. ${ }^{5}$

After the declaration of independence of Montenegro and the dissolution of the State Union of Serbia and Montenegro, the Republic of Serbia, based on the vision and the decisions of the state leaders, began the reform of the defense system (Medija centar "Odbrana“, 2005). The reform of the entire defense system included the reform of the communication system. The reform of the communication system consisted of the reform of its organization, its equipment and its training system. The reform of the TkIS communication system organization included establishing the TkIS organization, the composition and the locations of the TkIS commands, units and institutions. The Serbian Armed Forces communication system was reformed into the TkIS of the Serbian Armed Forces. Bodies, institutions and units for telecommunications and information technology with equipment and

\footnotetext{
${ }^{3}$ Sanctions on the Federal Republic of Yugoslavia were imposed on May 30, 1992. by the resolution of the UN Security Council.

${ }^{4}$ Among the numerous facilities were: Tower on Avala, Radio Television Serbia building in Belgrade, radio transmitters of Belgrade and other radio and television stations, "Telekom" in Uzice, the optical and other communication paths of the. "Telekom" and the Serbian Armed Forces on the targeted bridges, the capacities of the MUP of the Republic of Serbia, "Serbian Railways" and "Elektroprivrede Srbije".

${ }^{5}$ The rehabilitation of the most necessary infrastructure facilities for the work of TkIS was completed at the end of the first decade of the 21 st century.
} 
infrastructure are incorporated into the TkIS of the Serbian Armed Forces. The telecommunication and IT institutions deal with design, development, introduction and support in the exploitation of information and command and information systems as well as with research and development activities in the field of cryptography. Telecommunication and IT units are intended for the implementation of TKIOb at the tactical, operational and strategic levels. They are organized in communication squads, platoons, companies, batallions and the communication brigade. The composition, size and location of Tkl commands, units and institutions are in accordance with the size, composition, distribution of commands, units and institutions of the Serbian Armed Forces and the Ministry of Defense.

The damaged and destroyed facilities of the stationary TkIS of the Serbian Armed Forces were gradually revitalized in order to create the basic conditions for equipping and modernizing the TkIS with modern telecommunication and IT equipment. Equipment supply was carried out in accordance with equipment plans which were made on the basis of multi-year estimates and equipment plans. The stationary TkIS of the Serbian Armed Forces began to be equipped in 2008. The project of the Serbian Army radio-relay network "Saturn 5" foresees the complete replacement of radio-relay devices of the older generation and the connection of stationary nodes and stationary telecommunicationinformation centers with modern devices characterized by high speed, huge capacity and the possibility of integration with the TkIS holders in the Republic of Serbia. In order to realize the project, the purchase of telecommunication equipment from the manufacturer "NERA" was agreed (Nera Telecom, nd). The mentioned equipment was installed during 2009 and 2010. In addition to the mentioned radio relay network, significant capacities were renewed in the cable transmission system. Telephone exchanges were replaced, optical connecting paths were installed and various types of multichannel devices based on analog technology were replaced. All outdated cable connections and obsolete multi-channel equipment were replaced. The optical transmission system started to be fully operational in the Serbian Armed Forces. The modernization of the stationary TkIS of the Serbian Armed Forces has resulted in stability of the system, increased capacities and increased number of user services that can be offered to the command. The aforementioned equipping harmonized the organizational structure of the communication brigade, the number and the basic equipment for work on the elements of the stationary TkIS of the Serbian Armed Forces, established in 2006. 
Equipping the capacities of the mobile TkIS of the Serbian Armed Forces was realized to a much smaller extent than equipping the stationary part of the TkIS. Supply of modern equipment will be realized by importing modern telecommunication and information equipment from the French manufacturer "Tales" and the Israeli manufacturer "Tadiran". Priorities in equipping the TkIS mobile part were given to units sent to international operations, special brigade units, and the training center for informatics and electronic operations. Equipping other commands, units and institutions is carried out in accordance with the approved funds and according to the medium-term plan for equipping the Tkl commands and units of the Serbian Armed Forces and the Ministry of Defense.

By creating a new organization of the army, abolishing secondary professional military schools and adopting the decision to start voluntary military service, the Serbian Armed Forces applied a completely new way of recruitment and training (Službeni glasnik RS, 95/2010). The admission of soldiers to volunteer military service and their training for the needs of the telecommunications service is carried out at training centers for a period of six months. ${ }^{6}$ The education of non-commissioned staff in place of secondary education was replaced by professional training of professional soldiers - candidates from units who showed above average results at their workplaces in their units in the previous period. The same as in the previous period, training of candidates for officers is carried out at the Military Academy with adapted curricula in accordance with the trends in military management and school requirements.

The coordination and harmonisation of theTkIS organization of other holders in the Republic of Serbia for the purposes of the defense of the Republic of Serbia is carried out by the Telecommunication and IT Administration, in accordance with the powers of the Minister of Defense with the TkIS Administration for General Purposes as well as with special purpose TkIS administration bodies. Coordination and harmonization of activities relate to the acceptance of technical norms for enabling compatibility and interchangeability in Tkl capacities by assigning a certain part of TKI capacity for defense needs and aligning the research and development of TkIS elements of individual TkISs with the SAF TkIS and harmonization of joint activities in the realization of tasks of defense of the Republic of Serbia.

${ }^{6}$ Training soldiers in voluntary military service for the information service is not carried out. 
The reform of the Communication System in the TkIS of the Serbian Armed Forces covers the period from 2006 to the present. For the mentioned period, the multi-dimensional character of the TkIS of the Serbian Armed Forces reform has been reflected in: revitalization of the damaged TkIS facilities; creation of a new TkIS organization through the composition, size and location of the commands, units and institutions of the telecommunications and information service (and the improvement of the TkIS structural organization and the functional organization of the TkIS of the Serbian Armed Forces); equipping and modernizing the TkIS with modern telecommunication and IT equipment, improving the training of members of the telecommunications and information service and coordinating and harmonising the TkIS organization of other holders in the Republic of Serbia for the needs of the defense.

\section{Analysis of the impact of the current development} level of the telecommunication-information system of the Serbian Armed Forces on the defense of the Republic of Serbia

The influence of the achieved level of the development of the TkIS of the Serbian Armed Forces on the defense of the Republic of Serbia is reflected above all in ensuring the continuity, timeliness and quality of the functioning of command and control in the missions and tasks of the Serbian Armed Forces. Bearing in mind that TkIS of the Serbian Armed Forces is intended to secure the Serbian Armed Forces in the realization of their missions and tasks, the analysis of the achieved level of development of the TkIS Serbian Armed Forces on the defense of the Republic of Serbia will be heavily implemented in military defense. The analysis of the impact of the achieved level of development on the defense of the Republic of Serbia will be based on: analysis of the impact of structural organization TkIS VS (composition, size and location of commands, units and institutions of the telecommunications and information service), analysis of the influence of equipping and modernization of TkIS with modern telecommunication and IT equipment, analysis of the impact of improving the training of members of the telecommunications and information service, and analysis of the impact of coordination and colaboration of the organization of TkIS of other holders of the Republic of Serbia for the defense. 
Analysis of the impact of the structural organization of the TkIS of the Serbian Armed Forces on the defense of the Republic of Serbia

Regarding the structure, the telecommunications and information system of the Serbian Armed Forces consists of the stationary part of TkIS and the mobile part of the TkIS of the Serbian Armed Forces. The development of the existing infrastructure of the stationary part of the TkIS of the Serbian Armed Forces is based on real needs of command and control of the Serbian Armed Forces in peace, state of emergency and war. Most of the infrastructure facilities date back to the SFR Yugoslavia and were designed for the needs of the JNA's system of communications. The construction of these facilities was planned for the entire area of the SFRY, and the infrastructure facilities on the territory of the Republic of Serbia were part of the unique JNA system of communications. During the NATO aggression in 1999, most of the mentioned infrastructure facilities of the stationary part of the SAF TkIS were damaged or destroyed. In line with the priorities and economic possibilities, the existing ones were partially repaired and new facilities were built for the needs of the TkIS of the Serbian Armed Forces. Stationary telecommunication nodes (TKČs) are an element of the stationary part of the TkIS of the Serbian Armed Forces (Generalštab Vojske Srbije \& Medija centar „Odbrana“, 2012). Their placement, role and purpose make them an important element of the TkIS which enables the integration of command and control systems. By establishing radiorelay communication with the TkČ elements of the mobile part of the TkIS of Serbian Armed Forces, they realize the TKIOb for the needs of the command and units of the Serbian Armed Forces. The distribution of the TkČs in the Republic of Serbia and their interconnection ensures coverage of the majority of the territory of the Republic of Serbia. The analysis of the positions of these TkČs shows that they are relatively unevenly distributed, which is the consequence of the planning and construction of radio-relay facilities in the SFRY. The spatial inequality in the stationary TKČ distribution is more pronounced towards the border areas that represented the border areas in the SFR Yugoslavia with the neighboring countries: the Republic of Hungary, the Republic of Romania and the Republic of Bulgaria. In the other parts of the country, towards the regional borders, the situation in the arrangement of the stationary TKČs is more favorable due to the fact that these areas were not borderlines in the SFRY. After the NATO aggression against the FR Yugoslavia, three TKČs ceased operating in the AP Kosovo and 
Metohija, which complicates the implementation of the TkIOb in the southeast and southwestern part of Serbia, due to the size and shape of the territory. Moderately uneven distribution and the number of TkČs do not have a positive influence on the planning, organization and implementation of theTKIOb for military defense in the border regions of the Republic of Serbia.

Stationary telecommunication-information centers (TkICs) are an element of the stationary part of the TkIS of the Serbian Armed Forces. By their location, organization, people and equipment, they provide necessary preconditions for the implementation of TkIOb commands, units and institutions of the Serbian Armed Forces and organizational units of the Ministry of Defense. In most cases, the use of the TkIS capacities for general needs and other TkISs for special purposes is carried out by the Serbian Armed Forces and the Ministry through stationary TkICs. The locations of the stationary TkICs are conditioned by the locations of the Serbian Armed Forces commands, units and institutions and the organizational units of the Ministry of Defense. During the NATO aggression against the FR Yugoslavia in 1999, TkČs and TkICs were NATO targets as well. In line with priorities and economic possibilities, a number of the facilities have been repaired while new ones have been built to a smaller extent. Since 2006, when the reorganization of the Serbian Armed Forces started, some of the facilities have been abandoned due to the disbanding of units (garrisons and garrison sites). The arrangement of stationary TkICs in accordance with the existing organization enables the operation of the command, units and institutions in the Serbian Armed Forces as well as the operation of the organizational units of the Ministry of Defense in the areas of peacetime locations. The complexity of TkIOb commands, units and institutions of the Serbian Armed Forces in the areas outside the peacetime locations has been raised to a higher level in the state of emergency and war. The number, distribution and capacity of the TkICs in the entire territory of the Republic of Serbia have an impact on the defense of the Republic of Serbia and make the SAF TkIS more dependent on the use of the TkC capacities and those of "Telekom Srbija".

Stationary telecommunication paths (TkSPs) are an element of the stationary part of the TkIS of the Serbian Armed Forces. They are mediums for the realization of telecommunications between telecommunication stations (TkSts), TkICs and TkČs. They can be radio, radio-relay, wired and optical coupling paths. In the first decade of the 21 st century, modernization of cable communications was carried out, all 
outdated cable connections and multiplex equipment were replaced. The optical transmission system is the backbone of communications via permanent cables in the TklS of the Serbian Armed Forces. Through their locations, capacities and varieties, the stationary telecommunication paths positively affect the planning, organization and realization of the military defense of the Republic of Serbia. Taking into account the locations, distribution, organization, capacities and equipment of the TkČs and TkICs as well as the state of the TkSps, it can be concluded that the achieved level of the development of the stationary TkIS has a favorable effect on the defense of the country.

The mobile TkIS of the Serbian Armed Forces consists of portable and movable telecommunication and IT resources, as well as communication commands and units capable of working in field conditions. It is organized strategically, operatively and tactically. The TkI bodies are intended for planning, organizing, coordinating and controlling telecommunication-information security. The organizational structure of the Tkl organs in the commands, units and institutions of the Serbian Armed Forces was made on the basis of the intended and planned tasks to be performed by the Tkl organs and directly subordinate units. In the mobile TkIS of the Serbian Armed Forces, Tkl units are also organised at the tactical, operational and strategic level in communication squads, platoons, companies, battalions and the brigade. ${ }^{7}$ The organizational structure of Tkl units is tailored depending on their purposes, tasks and levels of command for which TKIOb is established. In order for a TkI unit to be efficient and functional in the implementation of TKIOb tasks, the organizational structure of the unit must be consistent with the purpose of the unit, the tasks performed by the unit, the composition of the personnel and the technique to be engaged in the implementation of tasks. The TkIOb Implementation Unit in a battalion - division is a communication squad, i.e. platoon. Tkl units in battalions - divisions are mostly equipped with Tkl equipment of the older generation for the realization of TkIOb. Regardless of the aforementioned problem, the current personnel and Tkl equipment in Tkl units in Tkl battalions divisions provide a high quality realization of planned telecommunications and services. A Tkl unit in a brigade, i.e. a unit of the same rank in the Serbian Armed Forces, is a communication company or platoon. A communication platoon in a Land Army brigade can fully implement the $\mathrm{TkIOb}$ at the brigade $\mathrm{KM}$, but due to the above-mentioned organizational

\footnotetext{
${ }^{7}$ A communication brigade has units of the battalion rank intended for operation in the stationary and mobile TkISs of the Serbian Armed Forces.
} 
solution (a communication platoon instead of a communication company), it is unable to establish a PTkIC at a brigade IKM and/or LoKM in order to provide necessary communications and services for commanding purposes, which negatively affects the organization of the defense of the Republic of Serbia at the tactical level. ${ }^{8}$ The reason for planning the existing organization of the communication units should be sought in the existing process of equipping with modern TkISs and devices. Equipping of the Tkl units is planned to be carried out in accordance with the Army's Integrated Communication System (ISV) equippment supply program, but due to an unfavorable financial situation it has not been carried out yet. As a transitional solution, some modern devices were installed in the existing communication systems, which improved the operational capabilities of commands and units and enabled the compatibility of the mobile TkIS with the stationary TkIS of the Serbian Armed Forces. At present, the personnel number and the equipment of Tkl units in other brigades or units of the rank of the brigade in the Serbian Armed Forces enable the planned telecommunications and services to be realised at a good level of quality. The units for the implementation of $\mathrm{TkIOb}$ at the strategic and operational level are a communication battalion of a communication brigade, the 21st communication battalion of the Land Army and the 210th communication battalion of the Air Force and Air Defense (SSNO, Uprava veza GŠ JNA \& Vojnoizdavački i novinski centar, 1988). The communication battalion of the communication brigade is intended for the implementation of TkIOb at the strategic level for the needs of the President of the Republic and the General Staff of the Serbian Armed Forces, while the TkIOb needs of the Ministry of Defense (and the President of the Republic to an extent) are dealt with by communication batallions of communication brigades from the stationary part of the TkIS of the Serbian Armed Forces. There is no obligation or jurisdiction of the TkIS of Serbian Armed Forces for the implementation of the TKIOb of other bodies: the Prime Minister of the Republic of Serbia, the Government of the Republic of Serbia, the President of the National Assembly and other state bodies. Telecommunication and information security of the highest state bodies for the purpose of the defense of the Republic of Serbia is defined by the Defense Plan of the Republic of Serbia (Službeni glasnik RS, 116/2007,

8 The task of the communication company is to set up a communication center at a brigade KM, PKM and IKM (when formed), establish planned communications, maintain the continuity of communications, enable their use, and ensure the security of communications and information (SSNO, Uprava veza GŠ JNA, 1990, p.3). 
$88 / 2009 \& 10 / 2015)$. Telecommunications of the cooperation and colaboration of the Serbian Armed Forces with the other elements are planned to be realized at the strategic, operational and tactical level in accordance with the needs of the defense of the Republic of Serbia and are prescribed by the Defense Plan of the Republic of Serbia (Službeni glasnik RS, 116/2007, 88/2009 \& 10/2015). For the realization of the telecommunications of cooperation and colaboration between the Serbian Armed Forces and the other elements of the Defense System, the capacities of TkIS of the Serbian Armed Forces, other TkISs for special purposes (TkIS of the Ministry of Internal Affairs, TkIS of the Ministry of Foreign Affairs, TkIS of the Security Information Agency, TkIS of the Serbian Railways, TkIS of the Elektroprivreda Srbije and TkIS of the authorities responsible for rescue tasks as well as emergency services) and most of TkISs for general needs ("Telekom Srbije" TkIS, "PTT Srbija" TkIS, "Radio-TV Serbia " TkIS, " VIP Telekom " TkIS, and " Telenor" TkIS). The organizational and formation structure of the communication battalion is in line with the purpose and tasks performed by battalions.

The organizational and formation structure of the bodies and units for telecommunications and informatics in the Serbian Armed Forces positively influences the defense of the Republic of Serbia due to the harmonization of the organizational and formation structure of the bodies and units for Tkl with the types and scopes of tasks, except for the units of Tkl in the Land Army brigades (due to an impossibility to realise some tasks to their full extent).

\section{Analysis of the impact of equipping and modernizing the} TkIS with modern telecommunication and IT equipment on the defense of the Republic of Serbia

In the current period (from 2000 to the present), based on the plans for equipping commands, units and institutions of the Serbian Armed Forces with telecommunication and IT equipment and the plans for the adaptation of facilities, infrastructure and capacities for the needs of the defense of the Republic of Serbia regarding the TkIS and TkIOb, a number of facilities have been built and the SAF TkIS elements have been equipped and modernized. Taking into consideration the economic possibilities as well as the estimates based on their importance and TKIOb use for the needs of the defense of the Republic of Serbia, the facilities damaged or destroyed by NATO forces were rebuilt or reconstructed or completely new buildings were built. The construction of 
completely new facilities or the repair of the damaged TkIS facilities has eliminated the negative impact of the availability of TkIS infrastructure facilities on the country's defense which was previously caused by reduced Tkl capacities and pronounced TkIS dependence on weather conditions, thus creating favorable conditions for proper accommodation of personnel and Tkl equipment.

Due to a poor economic situation and the imposed sanctions during the 1990s, modernization of the TkIS of the Serbian Armed Forces was not carried out. These events have led to a disproportion in the technological development of the TkIS of the Serbian Armed Forces and the TkIS of "Telekom Srbija" and there was a real technological inability to use the "Telekom Srbija" TkIS capabilities. By analyzing the existing TkIS capacities at the beginning of the 21 st century, it was concluded that the existing TKI equipment with its capacity, quality and technology would not meet the needs of the command and control system at the strategic, operational and tactical level for the defense of the Republic of Serbia. Procurement for the stationary TkIS of the Serbian Armed Forces was carried out in the period from 2008 to 2012. Modernization of the stationary TkIS of the Serbian Armed Forces has resulted in the stability of the system, increase of the capacity and the number of user services that can be offered to the command system, thus ensuring full integration of the SAF TkIS with other TkIS holders in the Republic of Serbia. The mentioned procurement brought in line the organizational structure of the communication brigade, the number of personnel and the basic equipment for work on the elements of the SAF TkIS stationary system established in 2006.

In accordance with the equipment supply plan for the mobile TkIS of the Serbian Armed Forces, the equipment supply was realized to a much smaller extent than the equipping of the stationary part of the TkIS. Priorities in equipping the mobile part of TkIS were given to the units referred to international operations, special brigade units, and the center for training, informatics and electronic operations. All commands, units and institutions are equipped with a certain number of modern devices that ensure the necessary compatibility with the stationary TkIS of the Serbian Armed Forces. Full equipment supply of the commands, units and institutions will be carried out in accordance with the approved funds and according to the medium-term plan for providing commands and units with Tkl equipment in the Serbian Armed Forces and the Ministry of Defense. Equipping and modernizing the TkIS with modern telecommunication and IT equipment moderately positively influences the defense of the Republic of Serbia due to incomplete supply of modern 
Tkl equipment to the commands, units and institutions of the mobile part of the TkIS of the Serbian Armed Forces.

Analysis of the impact of improving the training of members of the telecommunications and information services on the defense of the Republic of Serbia

Improving the skills of the telecommunication service personnel and the information service personnel is achieved through their education, training and professional development as well as through the training of the military reserve members.

Cadets are educated at the Military Academy or at colleges in the country or abroad, as before, and the curricula are adapted to the trends and educational requirements. By studying the content at the Military Academy, officers are prepared for their initial military duties in the telecommunications and information service. This way of training the officers for initial duties positively influences the defense of the Republic of Serbia, because it provides a quality cadre qualified for performing initial duties.

Instead of being educated in secondary schools, NCOs are the result of one-year professional training of professional soldiers candidates who showed above average results in their workplaces in their units in the previous period. This kind of training for a noncommissioned officer would make sense in the event of a greater flow of personnel, or engagement of non-commissioned officers in the Serbian Armed Forces for a certain period of time. Since the majority of noncommissioned officers obtain employment for an indefinite period after the completion of the course and promotion, after the renewal of the contract, the abolition of the secondary military school becomes unreasonable, and the training of the non-commissioned staff is displaced from the education system into the units. This way of training and teaching non-commissioned officers, in conditions when the inflow of military personnel is reduced and when new NCOs are employed for an indefinite period, does not positively affect the defense of the Republic of Serbia.

The training of soldiers in voluntary military service is carried out in military training centers. The training plan for soldiers includes two periods: the first one is a period of general military training and the second one is a period of vocational-specialist training. Training of soldiers includes all the training content of individual training, including the training of crewmembers. The current way of training soldiers for 
voluntary military service has the following disadvantages: training soldiers in voluntary military service does not include a sufficient number of soldiers to fill up war units (it is estimated that currently $1 / 3$ of the required number of soldiers is trained); there is currently no IT specialty for soldiers and, consequently, no training; soldiers who completed voluntary military service did not live and work in units and the period of collective training, which includes unit field exercises, was not realized; and it is not possible to fill vacant posts of professional soldiers by soldiers who voluntarily serve military service, thus violating the age structure of professional soldiers and reducing the percentage of complete units. This kind of training of telecommunication service soldiers negatively influences the defense of the Republic of Serbia for the aforementioned reasons.

Training of individuals, crews, units and commands of the telecommunications and information service is carried out in accordance with the Manual on Conducting the Training in the Serbian Armed Forces and the Training Instructions of the General Staff of the Serbian Armed Forces. This type of training provides freedom and responsibility for the commander to assess the skill levels, to plan and realize the training of individuals, crews, units and commands for the assigned mission. This mode of training positively influences the defense of the Republic of Serbia through cost-effectiveness, efficiency and effectiveness of training and the rationalization of the engagement of the telecommunications and information service staff.

Analysis of the impact of coordination and compatibility of the TkIS organizations of other holders in the Republic of Serbia for defense needs

The coordination and compatibility of the organizations of TkISs of other holders in the Republic of Serbia for the purposes of the defense of the Republic of Serbia are performed by the Telecommunications and IT Administration, in line with the powers of the Ministry of Defense with the Administrative bodies of theTkIS for general needs, as well as with the Administrative bodies of the TkIS for special purposes. Coordination and compatibility of activities relate to the acceptance of technical norms for enabling compatibility and interchangeability in the Tkl capacities by assigning a certain part of the Tkl capacity for defense needs and aligning the research and development of TkIS elements of individual TkISs with the SAF TkIS and aligning the joint activities in the realization of the defense of the Republic of Serbia. This way of coordination and 
compatibility of the organizations of TkISs of other holders in the Republic of Serbia positively influences the defense of the Republic of Serbia.

The achieved level of development of the TkIS of the Serbian Armed Forces in the defense of the Republic of Serbia is positively influenced by the structural organization of the Army TkIS (composition, size and location of the commands, units and institutions of the telecommunications and information service), equipping and modernizing the TkIS of the Serbian Armed Forces with modern equipment, training members of the telecommunications and information service service and coordination and compatibility of the organizations of TkISs of other holders in the Republic of Serbia for the defense needs.

\section{Conclusion}

By applying the concept of total defense, the Republic of Serbia enables equal participation of all parts of the society in the preservation and improvement of vital defense interests. The Defense of the Republic of Serbia consists of military defense and civil defense. Military defense is to be commanded and controled by the President of the Republic, the Minister of Defense and the Chief of General Staff of the Serbian Armed Forces in accordance with the Constitution, legal authorizations and their competencies. The bearer of military defense is the Serbian Armed Forces. The command and control of civil defense and other defense entities is to be carried out within state bodies, state administration bodies, autonomous provinces bodies, bodies of local self-government units, companies and other legal entities, in accordance with the law.

Telecommunication-information systems in the Republic of Serbia provide timely, complete and protected data and information for the needs of management, command and control of military and civil defense. With their own organizations and structures, these systems are interrelated, making a single, unified TkIS of the Republic of Serbia. Mutual compatibility of the TkIS for special purposes and the TkIS for general needs in the Republic of Serbia is one of the essential conditions for the realization of unified management, command and control of military and civil defense of the Republic of Serbia.

A telecommunications information system that enables the transmission of messages and information for the needs of military defense is the TkIS of the Serbian Armed Forces. Through its structure and organisation, the telecommunications and information system of the Serbian Armed Forces, according to a plan, realises the TKIOb of the 
Serbian Armed Forces. The telecommunications and information security of the Serbian Armed Forces is intended to ensure the continuity, timeliness and quality of the functioning of the command and control of the Serbian Armed Forces in all missions and tasks. The realization of TklOb enables networking in support of the visualization of the operational environment, the decision making process, the choice of action targets, synchronization of combat assets and tools, as well as information management.

The development of the TkIS of the Serbian Armed Forces has been based so far on the best world experiences and results of scientific and research work in the field of telecommunications, information technology and information protection. The achieved level of development of the TkIS of the Serbian Armed Forces in the defense of the Republic of Serbia is positively influenced by its structural organization (the composition, size and location of the commands, units and institutions of the telecommunications and information service) by its equipping and modernizing with modern equipment, by training members of the telecommunications service and IT services, and by coordination and compatibility of other TkIS organizations in the Republic of Serbia for defense purposes.

In order to improve the state of TkIS of the Serbian Armed Forces and achieve a completely favorable impact of the TkIS of the Serbian Armed Forces on the defense of the Republic of Serbia, it is necessary: to conduct a detailed analysis of the coverage of the entire territory with the signal of radio and radio relay devices from stationary telecommunication nodes and, in accordance with the analysis, to plan possible construction of new capacities at the long-term or medium-term level; to carry out a detailed analysis of the distribution of stationary TkIC centers and the coverage of the territory of the Republic of Serbia and, in accordance with the performed analysis, to plan possible construction or modernisation of the existing capacities; to adjust the organizational structure of Tkl units in the Land Army brigades to the scope of tasks; to equip Tkl units with modern Tkl equipment in accordance with the medium-term equipment supply plan; to plan to provide part of the training of soldiers in voluntary military service in the units of the Serbian Armed Forces in order for to them have collective training and acquire knowledge of the units of the Serbian Armed Forces; to consider a possibility of repealing the Regulation on termination of compulsory military service; to carry out a detailed analysis of the justification of the abolition of secondary military schools for non-commissioned telecommunications and information service officers; and, in order to 
support the TkIS of Serbian Armed Forces in the implementation of the $\mathrm{TKIOb}$ of the Serbian Armed Forces and the military defense, to conduct a detailed analysis of possible negative impacts of the announced privatization of "Telekom Srbija".

This work has a multifaceted significance which is reflected in: examining the place, role and significance of the TkIS of the Serbian Armed Forces in the defense of the Republic of Serbia, through the practical relationship and interdependence of the TkIS of the Serbian Armed Forces with the other TkISs in the Republic of Serbia and recognizing the importance of uniform technological and spatial development of the TkIS of the Serbian Armed Forces and the TkIS for general purposes for the defense of the Republic of Serbia. This work should serve as a basis for reviewing the state of the TkIS of the Serbian Armed Forces in terms of organization, equipping and modernization of the TklS of the Serbian Armed Forces, training of members of the telecommunications and information service, and the coordination and compatibility of the organizations of TkISs of other holders in the Republic of Serbia for the defense of the Republic of Serbia.

\section{References}

Aksentijević, M., \& Rošulj, B. 1984. Taktika veze. Belgrade: Vojnoizdavački zavod (in Serbian).

Generalštab Vojske Srbije \& Medija centar "Odbrana“. 2012. Doktrina telekomunikaciono-informatičkog obezbeđenja Vojske Srbije. Belgrade: Generalštab Vojske Srbije \& Medija centar "Odbrana“ (in Serbian).

Medija centar "Odbrana“. 2005. Bela knjiga odbrane Državne zajednice Srbija i Crna Gora. Belgrade: Medija centar „Odbrana“ (in Serbian).

Medija centar „Odbrana“. 2010. Doktrina Vojske Srbije. Belgrade: Medija centar „Odbrana“ (in Serbian).

-Nera Telecom. [Internet]. Available at:http://www.neratelecom.com. Accessed: 10.10.2018.

-North Atlantic Treaty Organization (NATO). [Internet]. Available at:http://www.nato.int/. Accessed: 10.10.2018.

Pečat. 2010. Spasoje Smiljanić, kako smo se branili od NATO agresije. [Internet]. Available at:http://www.pecat.co.rs/2010/03/spasoje-smiljanic-kakosmo-se-branili-od-nato-agresije/. Accessed: 10.10 .2018 (in Serbian).

Politika. 2014. Radio-amateri pratili bombardere od Avijana. [Internet]. Available at: http://www.politika.rs/scc/clanak/288103/Radio-amateri-pratilibombardere-od-Avijana. Accessed: 10.10.2018 (in Serbian).

Službeni glasnik RS. 98/2006. Ustav Republike Srbije. Belgrade: JP „Službeni glasnik“ (in Serbian). 


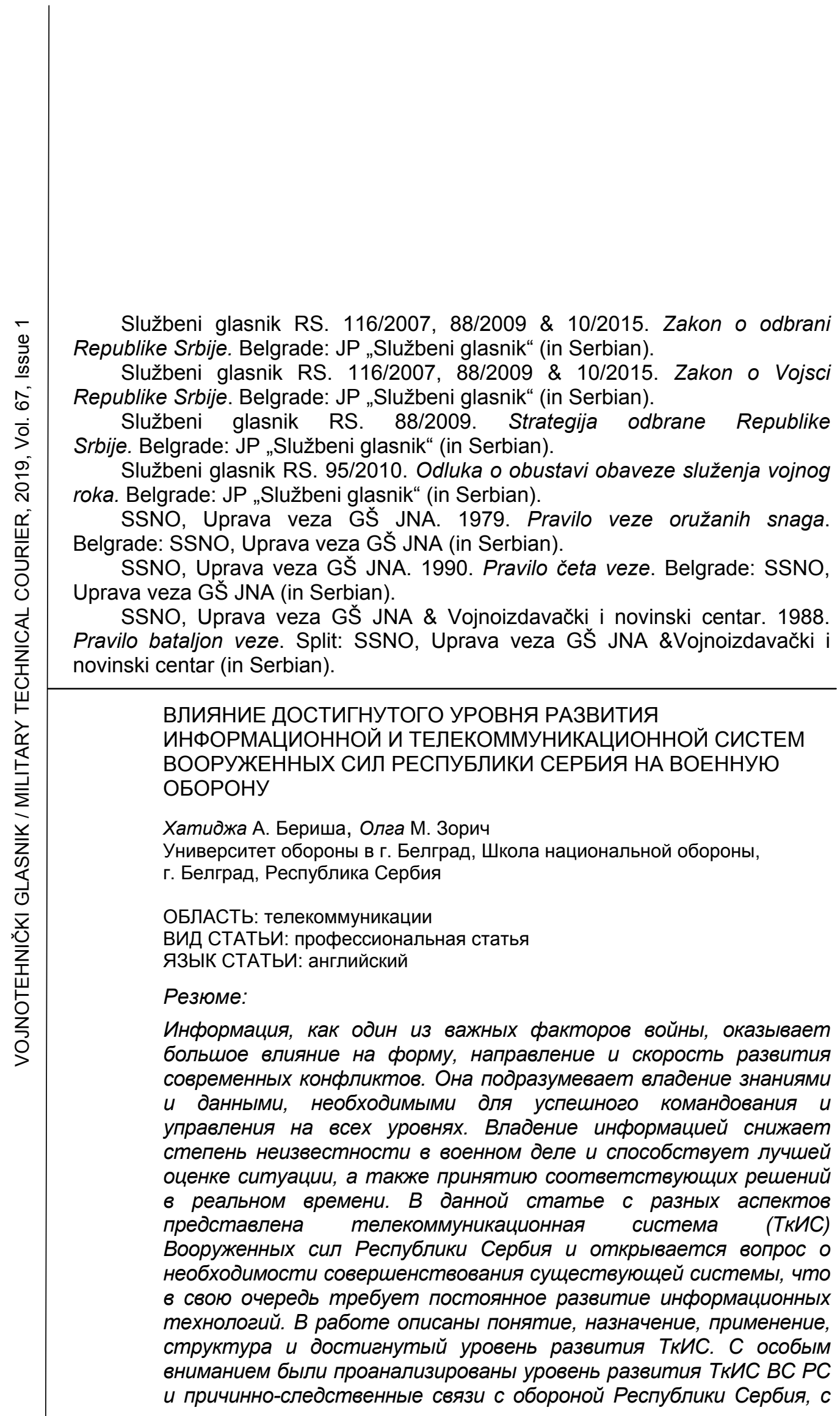


упором на военную оборону. Цель данной работы заключается в представлении того, каким образом информационная и телекоммуникационная системы Вооруженных сил Республики Сербия могут влиять на оборону Республики Сербия, особенно на военную оборону, нам также хотелось обратить внимание на необходимость постоянного совершенствования и развития ТкИС, то есть, в организации соответствующей и своевременной подготовки персонала для нужд военной обороны. Значимость данной работы заключается в проведенном анализе состояния телекоммуникационной и информационной систем Вооруженных сил Республики Сербия и представлении реальных нужд военной обороны Республики Сербия в контексте современных вызовов безопасности.

Ключевые слова: инфоормация, телекоммуникации, Вооруженные силы Республики Сербия, военная оборона, спутниковые сети, проводные сети, интернет.

УТИЦАЈ ДОСТИГНУТОГ СТЕПЕНА РАЗВОЈА

ТЕЛЕКОМУНИКАЦИОНО-ИНФОРМАЦИОНОГ СИСТЕМА ВОЈСКЕ СРБИЈЕ НА ОДБРАНУ РЕПУБЛИКЕ СРБИЈЕ

Хатича А. Бериша, Олга М. Зорић

Универзитет одбране у Београду, Школа националне одбране,

Београд, Република Србија

ОБЛАСТ: телекомуникације

ВРСТА ЧЛАНКА: стручни чланак

ЈЕЗИК ЧЛАНКА: енглесКИ

Сажетак:

Информација, као један од значајних фрактора оружане борбе, у великој мери утиче на фризиономију, правац и брзину развоја савремених сукоба. Она изражава расположивост знањима и подацима потребним за успешно командовање и руковођење на свим нивоима. Њеном расположивошћу смањује се неизвесност у војној делатности и омогућава се боља процена ситуације, као и доношење сврсисходних одлука у реалном времену. У раду се са више аспеката сагледава телекомуникационо-информациони систем (ТкИС) Војске Србије и актуелизује питање потребе унапређења постојећег система које намеће непрестани развој информационих технологија. У раду се наводе појам, намена, структура и достигнути степен развоја ТкИС. Детаљно су анализирани степен развоја ТкИС ВС и узрочно-последичне везе са одбраном Републике Србије, са тежиштем на војној одбрани. Циљ рада јесте да се сагледа утицај телекомуникационоинформационог система Војске Србије на одбрану Републике 
Србије са тежиштем на војној одбрани, као и да се укаже на потребу непрестаног усавршавања ТкИС и континуиране едукације, односно адекватне и правовремене обуке кадра за њихово коришћење у војноодбрамбене сврхе. Значај рада огледа се у анализи стања телекомуникационо-информационог система Војске Србије у односу на потребе војне одбране Републике Србије у контексту савремених безбедносних изазова.

Кључне речи: информација, телекомуникације, Војска Србије, војна одбрана, сателитске мреже, фриксне мреже, интернет.

Paper received on / Дата получения работы / Датум пријема чланка: 24.10.2018. Manuscript corrections submitted on / Дата получения исправленной версии работы / Датум достављања исправки рукописа: 05.12.2018.

Paper accepted for publishing on / Дата окончательного согласования работы / Датум коначног прихватања чланка за објављивање: 07.12.2018.

(C) 2019 The Authors. Published by Vojnotehnički glasnik / Military Technical Courier

(www.vtg.mod.gov.rs, втг.мо.упр.срб). This article is an open access article distributed under the terms and conditions of the Creative Commons Attribution license (http://creativecommons.org/licenses/by/3.0/rs/).

() 2019 Авторы. Опубликовано в «Военно-технический вестник / Vojnotehnički glasnik / Military Technical Courier» (www.vtg.mod.gov.rs, втг.мо.упр.срб). Данная статья в открытом доступе и распространяется в соответствии с лицензией «Creative Commons» (http://creativecommons.org/licenses/by/3.0/rs/).

( 2019 Аутори. Објавио Војнотехнички гласник / Vojnotehnički glasnik / Military Technical Courier (www.vtg.mod.gov.rs, втг.мо.упр.срб). Ово је чланак отвореног приступа и дистрибуира се у складу са Creative Commons licencom (http://creativecommons.org/licenses/by/3.0/rs/). 